\title{
Sport, Politics and Reunification - A Comparative Analysis of Korea and Germany
}

(Udo Merkel - School of Service Management, University of Brighton)

\begin{abstract}
Sport is a double-edged sword, it has the potential to bring divided nations together but it can also cause or exacerbate tensions and conflicts. Sport events do not only provide a stage for political rivalries but also increase understanding, celebrate commonalities, facilitate cooperation and bridge differences. This paper critically compares the use of sport as a foreign policy tool in two politically divided societies: Korea and Germany. The comparative analysis examines the very different political use of sport in these two countries. In divided Korea, cooperation in the world of sport between the North and the South is multi-dimensional, happens at various levels and appears to be an important diplomatic tool. In the former divided Germany, both the East and the West used sport to establish distinctive national identities and to fight ideological battles, even if it stressed differences and consolidated the existing political division. Furthermore, the recent increase in sport exchanges between South and North Korea offers a unique opportunity to examine the changing role and efficacy of contemporary sport diplomacy.
\end{abstract}

The research implicitly subscribes to the pluralist paradigm of International Relations as it avoids the limiting state-centrism of other theoretical frameworks. Therefore this investigation deals with all cross-border activities and recognises the contributions made by non-governmental organisation, for example sport organisations. The largely qualitative research was conducted 
during a six-month fieldwork period in South Korea in 2006 and a two-week visit of the North in 2008.

\section{Introduction}

At the end of the last millennium Sugden and Bairner edited an impressive collection of case studies focusing on and entitled "Sport in Divided Societies" (1999). The book covers a selection of European countries (Belgium, Germany, Northern Ireland, Spain, Switzerland) as well as developed and developing societies in various other parts of the world (Canada, Georgia, India, South Africa and Yemen). This choice was obviously the result of pragmatic as well as conceptual considerations. In their introduction the editors pointed out that

\footnotetext{
"It is a truism that all societies are divided. There are divisions between racial and ethnic groupings, between the rich and the poor, the young and the old, between men and women, adults and children, the healthy and the sick, and so on. All of these, and numerous other divisions, impact on the world of sport." [1]
}

Although sport certainly has the potential to overcome or at least reduce such divisions, many politicians and sport administrators tend to exaggerate sport's power to heal and bridge these divisions. Concurrently, they are often inclined to ignore or play down the fact that sport frequently causes, reinforces and exacerbates divisions. One of the International Olympic Committee's reasons 
for awarding the right to stage the 1988 Summer Games to Seoul was that it would support the process of reconciling South and North Korea. This did not happen as North Korea boycotted the Games and, in the ultimate unsporting act, blew up a South Korean airliner to put people off attending the Games. [2] FIFA, the world governing body of soccer, expressed a similar view when it granted South Korea and Japan the right to co-host the 2002 World Cup Finals. FIFA hoped that the tournament would help overcome 500 years of hostility between the two hosts. [3] There were even suggestions that some of the matches should be played in North Korea in order to help improve relations between the two Korean states. Although this did not happen either, the state controlled North Korean media occasionally reported on the outstanding performance of the South Korean team during the 2002 World Cup finals - a rare display of nationalism overcoming deep political differences.

At least two of the case studies in Sugden and Bairner's book, Germany and Yemen, could be grouped together as both societies were, broadly speaking, 'reunited' in 1990 after being divided along strict political lines. However, there is at least one other society that - although not (yet) unified - fits this description as it also comprises two independent sovereign states with totally different and opposing political and economic orders: Korea (Footnote I). Like Germany, Korea's division into the Republic of Korea (ROK) in the South and the Democratic People's Republic of Korea (DPRK) in the North stems from the 1945 victory of the Allied Forces in World War II. It was Korea's misfortune to be occupied by the armed forces of the two ideologically opposed superpowers which eventually led to the foundation of two Korean states in the late 1940s. However, in stark contrast to Germany the end of the Cold War has not brought reunification to the Korean peninsula. 
In the aftermath of the first Summer Olympics in China in 2008, it seems to be more than appropriate to reflect on the complex politics of sport on the divided Korean between 1990 and 2008. This paper intends to make a contribution to the wider area of comparative historical studies, in particular to debates about the role of sport in politically divided societies. It summarizes some of the findings of a research project which explored the role sport plays in the diplomatic activities between the North and the South. The dramatic increase in sport exchanges between South and North Korea since the early 1990s, all underpinned and framed by the reunification theme, offers a unique opportunity to examine the changing role, usefulness and political efficacy of sport diplomacy as the global sport order takes shape in the twenty-first century.

My analysis is based on data provided by the South Korean government, several sports governing bodies, the National Korean Olympic Committee, Korean academics and policy advisors of the government. The review of academic studies, policy papers and archive material, the collection of local, national and international media accounts, the attendance at various press conferences, the (semi-structured) interviews with government officials, sport administrators, journalists, and fans, and the (participant) observation of various sport scenes and events was conducted during a six-month fieldwork trip to South Korea in the first half of 2006 which was generously funded by the Korea Foundation (Footnote II). My research in North Korea took place in September 2008 during the official celebrations of the $60^{\text {th }}$ anniversary of the North Korean state. The focus was upon the political contents and messages of both the Arirang festival as well as the new mass spectacle entitled 'Prosper our Motherland'. A central theme of both shows, that were performed in Pyongang's impressive May-Day Stadium, was the division and reunification of the Korean people. 
Due to Korea's very complex past and present the following section presents a brief account of the nation's most important historical and political developments with particular reference to the complex reunification issue. This forms the basis for the following analysis of sport's contribution to the political and diplomatic relationship between the North and the South. As the social, cultural and political significance of sport during Germany's division from 1945 to 1990 and after the reunification process is well documented and widely studied, [4] the subsequent conclusion will outline the main comparative findings, i.e. commonalities and differences, and also briefly consider methodological issues.

\section{The Korean reunification debate: Don't rock the boat!}

Korea's twentieth century history is dominated by Japan's ruthless annexation which lasted from 1910 to the end of World War II. During this period sport was used as an instrument to express Korean nationalism and resistance to Japan's occupation. [5] In 1945, the armed forces of the Soviet Union and the USA occupied the country and helped to set up governments sympathetic to their respective ideologies and political leaders, leading to Korea's current political division and the parallel existence of two Korean states: the Democratic People's Republic of Korea with an estimated population of 23 million people in the North, established on 9 September 1948, and the Republic of Korea with more than twice as many people (48 million) in the South, founded on 15 August 1948. Shortly after the two superpowers pulled out most of their troops, on 25 June 1950, South Korea was invaded by the North starting the Korean War that is widely considered to be a proxy war in the wider context of the Cold War due the involvement of the USA and the Soviet Union. China also entered the conflict in order to protect its national 
security as it felt threatened by the increased American military presence in South East Asia. Furthermore,

\begin{abstract}
"Mao determined early in the war that if the North Koreans faltered, China had an obligation to come to their aid because of the sacrifice of so many Koreans in the Chinese revolution and he anti-Japanese resistance" [6]
\end{abstract}

After a truce was signed with the North (1953), a demilitarized zone (DMZ) was established along the thirty-eighth parallel.

The economic miracle in South Korea is well documented and has been widely investigated. Copying the Japanese model of economic growth largely based on the export of popular mass consumer goods, production increased significantly in the 1970s and 1980s. [7] Despite a severe recession following the 1997 Asian financial crisis, South Korea today enjoys a robust and healthy economy. [8] During the Cold War, the North frequently exploited the tense relationship between its two main benefactors, the Soviet Union and China, and also achieved astonishing progress in standards of living. However, since the disintegration of the former Soviet Union and its Socialist allies most of the markets for North Korean products have all but disappeared. Famines have repeatedly swept through the country in recent years, caused by a combination of unfortunate weather conditions and inadequate agricultural management policies. Consequently, the North has slowly slid into poverty and is often called the 'Hermit Kingdom' for its closed borders and reluctance to deal with outsiders. [9]

More than six decades after the end of World War II, the two Korean states face each other across the highly fortified DMZ where the Cold War was more 
frigid than anywhere else in the world and has not (yet) ended. Although the Cold War ceased in 1989, the persistence of Cold War structures and hostilities makes the Korean peninsula look like an interactive and topical museum of that global ideological and geopolitical conflict. Both Korean states proclaim eventual unification as a high priority political goal. Consequently, the unification of the Korean people and peninsula is an essential feature of both Koreas' political agendas and discourses. [10] Although there are some lively debates about how the Korean peninsula can be reunited, there is widespread scepticism that this is going to happen in the foreseeable future. Generally, the status quo of two co-existing Korean states is beneficial to all parties concerned, most of all the two Koreas as well as the two superpowers of China and the USA.

There is no doubt that the South Korean government does not want the sudden collapse of the North Korean regime due to the enormous costs it would have to bear. "The financial burden of unification which South Korea will have to absorb has been estimated at ten times greater than that of West Germany, related to Germany's reunification." [11] Furthermore, South Korean political analysts are worried that such a collapse could set several destabilizing developments in motion: Millions of North Koreans suddenly crossing the border into the South could quickly overwhelm South Korea's refugee support capacities and would have an enormous negative impact on the country's economy. Therefore Seoul's political priority is stability which precludes precipitating an abrupt collapse of the North Korean regime. For that reason the South Korean government has in fact frequently helped the North Korean state to alleviate the poverty its population has been suffering from through the provision of food, building materials, energy and other basic goods. 
Although "South Korea has become North Korea's second biggest trade partner and aid provider", [12] a lot more needs to be done to mitigate the anticipated massive costs of unification, if and when it happens. South Korea will find it economically even more difficult than West Germany to absorb their 'friends in need'. Not only is the North Korean economy in much worse shape than the East-German was before the wall came down in 1989, but more importantly for many Koreans the simple numerical relationship of two South Koreans paying for one North Korean (in comparison to four West Germans per one East German) appears to be a daunting prospect which partly explains the widespread caution and growing scepticism among the South Korean population. [13]

Furthermore, the status quo of a strong American military presence in South Korea (Footnote III) has a number of economic benefits: "The US alliance creates a climate of stability favourable for foreign trade and investment and for preferential economic treatment by international financial institutions, exemplified in the 1997 International Monetary Fund (Footnote IV) bailout." [14] Indirectly, the US military presence also provides a very large economic subsidy to South Korea. Without this US military presence, the South Korean government would have to triple its military budget if it wanted to keep up the levels of defence following a withdrawal of the American armed forces.

Equally worrisome for Seoul (as well as the USA) is China's potential reaction to such a collapse as this superpower could either intervene directly or orchestrate a coup and install a pro-China regime that would further complicate a peaceful Korean unification. China's quiet opposition towards unification is based on its reluctance to share an extensive border with a unified democratic Korea closely allied with the United States. So far, China 
has provided North Korea regularly with economic aid to support the regime in order to avoid political instability in the area.

"One remarkable feature of North Korea's external environment after the collapse of the socialist states in many parts of the world is that all of the four surrounding powers -- China, the U.S., Russia and Japan -- are against the collapse of the North. Preoccupied with its domestic affairs and afraid of the negative impact of North Korea's sudden collapse on itself, each of them is trying to help stabilize North Korea in one way or another." [15]

Over the past fifty years the reunification of the Korean peninsula has also been one of the most frequently expressed foreign policy objectives of the North Korean government. Its approach to unification is understandably very different. "The Korean War (1950-53) was a catastrophic attempt on the part of North Korea to unify the peninsula by the use of force." [16] Since the early 1990 s the survival of North Korea has been threatened by various internal and international developments: the rapid deterioration of living standards caused by the failure of the centrally planned economy and excessive defence expenditure which led to negative growth rates in the early 1990s; the lack of political and economic support due to the collapse of the former Soviet Union and the Socialist countries in Eastern and Central Europe which deprived North-Korea of major (export) markets; and the extremely strained relationship with the USA due to North Korea's attempts to develop nuclear weapons. Consequently, the government's political focus has shifted. Economic regeneration, system survival and the security issue are more urgent than the development of detailed reunification proposals. Furthermore, taking measures to improve its reputation as a politically stable state are 
essential to attract the desperately needed foreign investments to boost its economy.

Due to these large obstacles it is most unlikely that the reunification of the Korean peninsula is going to occur in the near future. However, considering the two Koreas remain technically still in a state of war, there has been some major progress over the last years. The world of sport acts as a kind of frontrunner and pace-setter for the development of various forms of political cooperation. Sport exchanges and co-operations are also viewed as a fairly accurate reflection of the general political climate on the divided peninsula.

\section{"Peace and Prosperity" through sport}

During the Cold War period South Korea went through significant social, political and cultural changes. The world of sport did not remain unaffected and went through a rapid transformation process that was initiated by the Park Jung Hee military regime in the early 1960s. Park's government (1961 - 1979) is responsible for the foundation of many of the existing sporting organisations and developed some influential policies that were intended to enhance the country's international reputation and prestige. Subsequent governments, in particular the Fifth Republic of Chun Doo Hwan (1981 1988) and the Sixth Republic of Roh Tae Woo (1988 - 1993), continued this project with a strong emphasis on the promotion of sport for the creation of a distinctive national identity and international recognition. [17]

With political endorsement, government resources, an effective strategy, public support and an enthusiastic educational system, in less than 50 years a revolution in sport in schools occurred in the interests of national defence, 
national self-reliance, national visibility, and national prestige. [18]

During this period international sport events provided an ideological battleground for the two Korean states both claiming to be the true representative of the Korean people. Either they refused to participate in protest of the other's presence or, when they competed against each other, the rivalry was fierce. At the same time, the media (as well as school books ) portrayed the North and its Communist regime as a devious and dangerous enemy who could not be trusted and was a threat to the national security of the South. These times are over, at least for now, as the 'Sunshine Policy' of the previous South Korean government aims for peace, reconciliation and prosperity on the whole Korean peninsula. This is clearly reflected in the increasing number of inter-Korean sport meetings, exchanges, programmes, symbolic gestures and future cooperation plans. The following account has chosen some representative examples of cross-border activities and recognises the contributions made by sport organisations, e.g. national governing bodies and local bidding committees, as well as the media covering these events. It is the latter that provide for fairly direct mass participation in the 'high' politics of international relations.

'Peace and Prosperity' is the title of the South Korean 2005 White Paper on Unification. In this extensive and detailed policy document of more than 170 pages, however, sport can hardly be said to play an important role. It is only mentioned twice: first in Chapter 2 entitled 'Progress in Inter-Korean Dialogue' focusing on joint activities during the Sydney (2000), Athens (2004) and Beijing (2008) Olympics and subsequently in Chapter 3 summarizing the 'Expansion of Inter-Korean Exchanges and Cooperation' which celebrates the joint processions of the South and North Korean teams 
at the Busan Asian Games (2002), the Aomori Winter Games (2003) and the Daegu Summer Universiade (2003). [19] However, it is striking that this White Paper does not contain any clear and detailed policies in relation to sport. One interviewee, a researcher and policy advisor of the URI government, had a simple and straight-forward explanation for this: "Sport is very complex. The Seoul Olympics and the Soccer World Cup have been good for this country's reputation and economy. So, whenever the North and the South do sports together, it is good for the whole nation - whatever kind of sports this is, wherever it happens, who wins, it does not matter as it is all about unity." (13/03/2006)

In sharp contrast, in the 2004 collection of 400 photographs on over 200 pages entitled 'The History of the Development of Inter-Korean Relations', published by the Advisory Council on Democratic and Peaceful Unification, sport plays a much more prominent role. A total of 30 photos (i.e. about 15\%) show sport events, athletes or venues. Most prominently, the front cover of the book shows North and South Korean football players in the World Cup Stadium in Seoul. Almost all the captions contain the word or make reference to 'unification' theme. Although a few of the images are over 50 years old and stem from the early stages of Korea's political division, the vast majority of sport photos derive from activities in the twenty-first century. Two parallel strands of political activities involving the world of sport of sport can be easily identified: First, the mostly symbolic and short-lived but high profile appearances as a unified team on the international stage, and, second, the celebration of national unity through the frequent staging of 'unification sport events' in both the North and the South.

\section{Marching and competing together at international competitions}

Since the North Korean boycott of the 1988 Seoul Olympics, the relationship between the two states in the world of sport has significantly improved. Both Koreas have on various occasions formed a unified team for international sport events, i.e. at least for the official opening and 
closing ceremonies. On a much smaller number of occasions have they even competed as one team.

Three years after the Seoul Olympics, athletes from the North and the South competed as one team in the World Table Tennis Championships in Japan and eventually won the women's team event beating the invincible powerhouse of this sport, China. Prior to the tournament, the two sides had failed to agree on the location of the training camp for this competition, and eventually ended up having a 40-day joint training session in Japan. Most remarkable, however, was the use of a new symbol which was to become a permanent accessory at several international and domestic sport events in the $21^{\text {st }}$ century: the unification flag, a white flag with the shape of the Korean peninsula embroidered in a deep blue colour. In the same year a joint soccer team participated in the FIFA World Youth Championships in Portugal where they made a big impression by reaching the quarter-finals after beating Argentina 1-0 in group qualification.

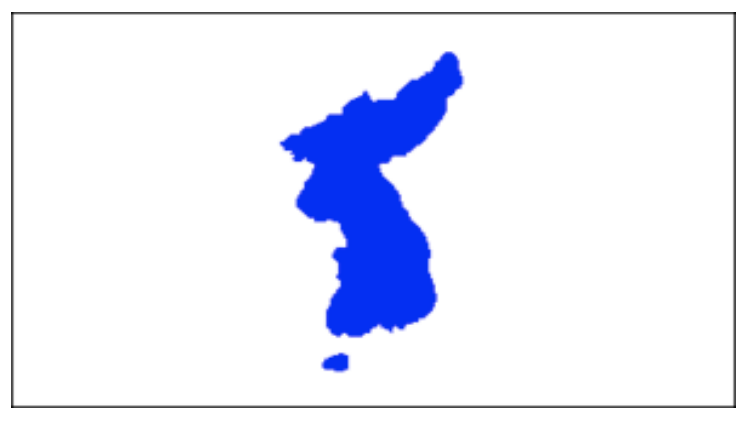

Fig.1 The Korean Unification Flag

When the two Korean teams marched together at the 2000 Sydney, 2004 Athens and 2006 Turin Olympic opening ceremonies they were again united behind the unification flag. Initially Juan Antonio Samaranch, the then Olympic president, had proposed that all Korean athletes march jointly under the Olympic flag, which would be followed by the flags of each 
country. South Korea accepted this proposal whilst North Korea argued that there was no need for the Olympic and the two national flags since both countries' ultimate goal is reunification. The name 'Korea' was used to represent the two countries during the opening ceremony, and the presidents of both nations' Olympic committees followed the two flag bearers (one from each country) in front of the athletes and coaches.

One of the biggest surprises, however, for the Olympic community happened in November 2005 when sport administrators from both countries agreed in principle to form a unified team for the Beijing Olympics 2008 in China. The deal, struck on the sidelines of the East Asia Games in Macau and supported by the International Olympic Committee, followed years of inter-Korean talks. "The significance of this is we will be going onto the world stage as a unified team, and this will serve as a symbol of reconciliation and cooperation," a South Korean Unification Ministry official told me in an interview in May 2006. There was no doubt that the Chinese would like to see a unified Korean team to participate in the Beijing Olympics in 2008, as they welcomed the announcement enthusiastically. It would not only distract from the continuous discussions about China's poor human rights record but also provide the Beijing Olympics with a lasting political legacy. Even the usually reserved Jacques Rogge, president of the IOC, appeared to be delighted whilst acknowledging that there are still some obstacles to overcome. In a press conference in Seoul on 4 April 2006, he stated that "Joining the march at the Olympics is definitely a symbolic issue, but it is still different from building up a unified team of the two Koreas". A few days after the press conference I interviewed two fairly senior South Korean sport administrators of the National Olympic Committee who were supportive but skeptical as there were "too many stumbling blocks" (12/04/206). They could foresee several problems: Firstly, the principles underlying the actual selection of athletes; second, harmonizing training methods; third, agreeing lines of communication and responsibilities; and finally, finances.

There was, however, little doubt that the two Koreas would continue using the blue and white unification flag. Furthermore, there seemed to be some kind of consensus among South Korean sport administrators (even before the negotiations started) that the anthem of the team would be 'Arirang', a 
traditional love song popular in both Koreas, and that Seoul will have to assume the vast bulk of the costs.

In comparison, in the early 1960s, the IOC, at that time headed by Avery Brundage, insisted that for the 1964 Olympic Summer Games in Tokyo, Japan, the first Olympics in Asia, a joint German team, officially called "United Team of Germany", should be formed. "The incredible difficulties which occurred thereafter in forming a joint German team ... led to a total of 15 National Olympic Committee conferences and 96 meetings of the sport associations of East and West Germany. Over a thousand hours of discussions took place." [20] Although it was the last time (before reunification) that a joint German team would compete in the Olympics, the IOC stipulated that both teams had to continue using a banner comprising the colours black, red and gold with the five Olympic rings in white set in the centre.

Eventually Korea did not compete as one team at the Beijing Olympics due to insurmountable differences on the principles underlying the selection of athletes. The North demanded equal representation, whilst the South insisted that athletes should be chosen on the basis of their performance, prior achievements and world standing. Nevertheless, for many political commentators the declaration of intention itself represented a major breakthrough, another sign that North Korea was edging out of its isolation, and a new milestone for inter-Korean efforts to go one step further in their cooperation. North Korea's willingness to constructively engage with the South in discussing sport matters (and gradually to abandon its isolationist politics) was further stressed by the participation of a high-profile North Korean delegation in the 15th General Assembly of the Association of the National Olympic Committees (ANOC). The ANOC was held in Seoul from 31 March to 7 April 2006 under the auspices of the South Korean Olympic 
Committee. The South and the North took advantage of this meeting as a venue and also held private talks about various inter-Korean cooperation issues but did not reveal any details.

For the near future, there are preliminary plans to host the Gumball Rally, a glitzy race of ultra luxury cars driven by multi-millionaires, spanning the entire Korean peninsula. Although it is unlikely that any Koreans will participate in the race, it is the crossing of the DMZ, i.e. a temporary opening of the border between the two countries, which is of significant symbolical value.

\section{Intra-Korean sport events, exchanges and programmes}

Inter-Korean sport events, usually referred to as 'unification ... matches' (with the name of the sport to be added), also started in the last decade of the last century. In October 1990, 'Unification Football Matches' took place, the first events of this kind to be held in both capitals, Seoul and Pyongyang. The friendly, small-scale tournament, which became possible through talks between the sport ministers of the two Koreas during the Asian Games in Beijing earlier in the year, paved the way for further sporting co-operations in the divided nation and led to a variety of inter-Korean sport events that have become more frequent in the new millennium. The 'Inter Korean Unification Soccer Match' on 7 September 2002 took place in the World Cup Stadium in Seoul and was even sold out. ( Footnote V) Within a few years, the blue and white unification flag became so popular that the vast majority of young soccer fans wore them as T-shirts during a match between the two Koreas in August 2005. Even the well known Red Devils fan group swapped their traditional outfit for this powerful symbol and through the chanting of "Jokuk Tongil" called for the reunification of Korea.

Since soccer is a popular sport in both countries, the South even sponsored the North and, in 2005, provided their neighbours with a complete set of shoes, shirts, bags, etc. worth 100 million Won $(\$ 97,000)$. After the North Korean soccer team's sponsorship contract with Fila, an Italian sportswear manufacturing company, expired in 2002 the Football 
Association struggled to find a new sponsor. Eventually, in January 2005, the Korea Soccer Research Institute decided to step in.

Other sports have followed soccer's example and have organised similar events. In 2000, the first 'Unification Basketball Tournament' was held in the capitals of the two Koreas. Following the first couple of games, where the men's and women's All-Star teams played their Northern counterparts in Pyongyang in September, two more games took place in Seoul in December. The Pyongyang games were the first sport events in North Korea to be televised in South Korea.

How determined the organisers of these unification events are to convey the right message shows the following example: In February 2006, when the national women's ice hockey sides of both countries met for a friendly match in Seoul, one of the South's best players, Hwang Bo Young, was kept off the ice. She had to watch the game from the stands as she had fled from North Korea in 1997 aged 19. In the spirit of peace and friendship even the rules of this match had been changed and checking on the ice was not allowed. [21] Only one month later the Kangwon province invited a North Korean ice hockey team to play a friendly match in the South. This did not lead to a competition between North and South, as two mixed teams were formed each comprising athletes from both countries. Even the teams' names URI (meaning 'we') and HANA (meaning 'one') reflected the reconciliatory spirit of this event. Equally important in practical and symbolic terms was the way the North Korean team travelled to the South. The team used the Tonghae Highway making it the first time North Koreans officially visited the South via a land route since the Korean peninsula was divided in 1945.

Although the majority of unification sport events are initiated by and take place in the South there are also a few occurring in the North. On 24 November 2005 a group of 150 marathon runners flew directly to Pyongyang to participate in the 'Pyongyang-Nampho Marathon for Reunification'. North 
Korean speakers at the opening ceremony suggested that the marathon provided an occasion to demonstrate "the Korean nation's firm resolution to work hard for the reunification of the country under the banner of the June 15 joint declaration, a landmark for independent reunification. Men and women runners from the north and the south ... determined to reunify the country at any cost by the concerted efforts of the Koreans." [22]

The reunification theme also featured prominently in the unsuccessful bid of Pyeongchang, a small town in the above mentioned Kangwon Province in the North-East of South Korea, to host the 2014 Winter Games. This was Pyeongchang's second attempt, after it was defeated in 2003 with Vancouver winning the rights to host the 2010 Winter Olympics. As before, Pyeongchang's campaign drew on a mixture of economic, sport and political arguments to convince the IOC. In addition to tourism development and boosting the popularity of winter sports in the Asian world, Korean reunification was the most dominant theme of the official application form.

The second paragraph of the introduction to this document introduces the issue in very theatrical and dramatic terms: "A people divided into South and North, the citizens of Korea stand united in respect for 5,000 years of tradition. There is a single Korean heart beating in tune with the rhythms of nature. A single spirit that soars across the peaks and valleys of this beautiful land." The following pages go into greater depth and reveal more details of the 'Hopes for Reconciliation with North Korea'.

This is not only marketing rhetoric but also the leitmotiv for a number of high profile as well as grass-roots sport initiatives in this part of South Korea. The Kangwon province, that shares a border with North Korea, has run a series of inter-Korean sport exchange programmes over the last few years. In 2007, the province invited children from North Korea to participate in the 'Dream Programme', which provides young people from countries with a climate unsuitable for winter sports with first-hand experience of such 
sports. A year before, in February 2006, 110 youths from 30 countries across Asia, Africa, Latin America and Europe had participated in this programme. Obviously, these activities were intended to have a positive impact on the decision-making process of the IOC but they also kept the idea of reunification in the media headlines. In a newspaper interview Kim Jin Sun, the governor of the Kangwon province confirmed this twofold rationale:

"We have been trying to hold various inter-Korean sports exchanges to help ease the tension between the South and North. I think holding joint sports events is the best way to improve the relations and bring peace to the Korean Peninsula. ... Prospering sports exchanges and cooperation will give Pyeongchang an advantage over other contenders because hosting a Winter Olympics here will help promote world peace and solidarity through sports, which is the true Olympic spirit." [23]

In November 2006 North Korea conducted another nuclear test, which raised tensions on the Korean peninsula. The only dialogue which continued focused upon sporting issues. Although political communication was reduced to a minimum, the governor of the Kangwon province and executive president of the Pyeongchang bidding committee, Kim Jin Sun, even visited North Korea for four days to discuss an expansion and the principles of future cooperation in the world of sport.

The South Korean mass media have also reacted to these developments and started to pay more attention to sport events in which North Korean athletes and teams are involved. Their achievements at the Athens and Beijing Olympics were noted and celebrated, and North Korea's qualifying matches for the 2006 Soccer World Cup in Germany were even broadcasted live. Newspapers have also started to treat outstanding North Korean sportsmen and women as if they were their own. The gold medal of Pak Hyon Suk at the Beijing Olympics, a female North Korean weightlifter, was widely celebrated in the South Korean print media whilst the use of 
beta blockers and subsequent expulsion of Kim Jong Su, who won two medals in the shooting competitions, were treated as low-key incidents emphasizing that "The North still stayed within the top 20 in the overall medal standings" [24] The coverage of both TV and print media is extremely friendly, favourable, enthusiastic and positive, often stressing the deep bonds and ethnic ties between the two Koreas. Several male and female, middle-aged, well-educated interviewees were very surprised about this dramatic development and stressed the stark contrast between the representations of North Koreans they remembered from their school books ("bad", "malicious", "dangerous", “evil”, "devils", "demons", "warmongers") and the overwhelmingly positive and inclusive contemporary characterizations.

\section{The Arirang festival: North Korea's propaganda and new foreign policy toy}

Physical culture has recently started to play a more important role in North Korea's domestic and foreign propaganda agenda in order to demonstrate the uniqueness, strength and stability of its political system, to display Kim Jong Il's popularity and his ability to control the country firmly. Most notably in this context is the Arirang festival, an impressive spectacle of gymnastic and artistic extravaganza that premiered on 29 April 2002 to mark the $90^{\text {th }}$ anniversary of the birth of the 'Eternal President' Kim Il Sung (1912-1994). The Arirang festival also celebrated the $60^{\text {th }}$ birthday of Kim Jong $\mathrm{Il}$, the 'Dear Leader', who inherited power from his father in 1994, and the 70th anniversary of the founding of the Korean People's Army. "True to the North's way of doing nothing by half, it dwarfs anything seen even during the heyday of the far more prosperous communist regimes of the former eastern bloc." [25]

In 2002, this festival was scheduled to distract attention from the parallel World Cup in the South and - most importantly - prove it is not the evil place depicted by President George W. Bush. Its sequel took place in October 2005 
to celebrate the 60th anniversary of the North Korean Communist Party. As before, the stage was the 150,000-capacity May Day stadium in Pyongyang and the 90-minute show made full use of the impoverished nation's last natural resource: cheap, utterly obedient and highly educated labour. In 2008 , the Arirang festival celebrated the $60^{\text {th }}$ anniversary of the foundation of the North Korean state. Furthermore, a new show ('Prosper our Motherland') had been put together drawing on the same ingredients and telling the story of the DPRK.

The performance with its endlessly rehearsed and flawless choreography comprised two distinctive elements: a floorshow by several thousand gymnasts, acrobats, dancers and other performers including: a military tattoo, a martial arts display, hordes of waving, smiling children, an aerial ballet by dancers on bungee ropes, displays of rhythmic gymnastics, flying acrobatics, traditional dancing and military taekwondo routines. The most breathtaking element of Arirang was the backdrop - a giant human mosaic that formed elaborate panoramas of historical scenes, individuals, slogans, objects and cartoons. More than 30,000 children held up coloured cards and changed them so quickly that these pictures appeared to be animated - all totally synchronized to a massive video and laser light show. Obviously, such a spectacle is major propaganda offensive and a public demonstration of North Korea's pride and self-confidence. There are three remarkable issues which need to be addressed in more detail: First, as well as underpinning the religious cult of Kim Jong-Il and his father, the 2005 festival marked the beginning of an international charm offensive. Not since the euphoric summit between the North's leader and South Korea's president Kim Dae Jung in June 2000 (Footnote VI) had there been such a show of openness in Pyongyang. During the festivities foreigners were allowed to enter the country that only has 300 recorded foreign residents. Even Americans widely referred to as 'mije chimnyakja' ('American imperialist aggressors') were 
able to obtain visas and enter North Korea in 2005. "Among them have been New Mexico Gov. Bill Richardson and former CBS News anchorman Dan Rather. The festival brought official delegations from China, Russia and Cuba as well as high ranking visitors from Mexico and a host of other nations." [26] Along with a growing number of curious Western spectators, in 2005 ordinary South Korean citizens were for the first time ever allowed to fly directly from Seoul (Incheon) to Pyongyang (Footnote VII) and attend the Arirang spectacle. Approximately 1,000 South Koreans made the Arirang pilgrimage on overnight package tours. Kim Jong Il's 'invitation diplomacy', a political tool his father used to exploit to great effect, is intended to show how strong and stable North Korea is, how firmly he is in control and how popular he remains with the people. This message would not get out loud and clear, unless there were select groups of foreigners there to witness it. Three years later, however, South Koreans were not welcome (and Americans only allowed to stay for a very short period of time) which clearly reflected the political climate.

Second, in 2005 one short segment of the performance disappeared after South Korean media complained about the offensive contents. In the show three North Korean martial arts specialists kicked, punched and subdued 30 unnamed enemies. But there was a clue: the 'enemies' wore uniforms identical to those which were used by the South Korean armed forces before 1990. "Unification Ministry and intelligence sources said the North Korean leader Kim Jong-il watched the show Sunday and that his "on-the-scene inspection" may have triggered the cut." [27] This last minute alteration must be interpreted as another small gesture among many of the reconciliatory spirit and confidence in evidence in North Korea.

Third, the issue of reunification played a major role in the 2005 and 2008 spectacles. Both the fourth act ('Arirang Reunification') and the 'Grande Finale' focused on the reunification issue. 
Participants held up coloured cards creating a montage of South and North Korean children, while chanting "How much longer do we have to be split due to foreign forces?" [28] A different segment features the 'reunification train' - a reference to a new railway link across the DMZ. The same train as well as several other related themes, e.g. the joint declarations on Korean unifications, featured prominently in the third act of the new "Prosper our Motherland" show. The unification scenes also contained several references to Mount Baekdu, an important place in both South and North Korean mythology. The mountain is located in the North along the border with China and it is not uncommon for South Korean tourists to travel to the Chinese side for a visit of this mountain of mythical resonances.

\section{Conclusion: Commonalities and differences}

The ultimate purpose of any comparative analysis is to identify, explain and evaluate commonalities and differences providing that the two societies in question are in fact comparable. The large number of socio-historical and political similarities in the twentieth century leaves little doubt that comparing Korea and Germany is a legitimate and useful exercise. However, the following contextual differences need to be acknowledged:

First, the two countries are located in very different parts of the world and influenced by distinctively different philosophical and cultural traditions. Second, Korea's industrialisation and modernisation occurred much later than Germany's, i.e. in the second half of the twentieth century, and was carried out with unprecedented speed. Third, in the aftermath of World War II, Germany did not suffer from a gruesome civil war which killed millions of soldiers and civilians, and which will make the unification of the Korean peninsula even more difficult. "It is very hard to believe that the People's Army commanders who fought the South in such a bloody fracticidal war would allow the ROK to overwhelm the DPRK, by whatever means." [29] Fourth, whilst the Russian troops left North Korea in 1948, East Germany hosted 360,000 Soviet military personnel until 1990. However, the Soviet 
leader Mikhail Gorbachev decided not to mobilise these troops when the East German regime under Erich Honecker started to collapse in the autumn of 1989. Despite these contextual differences both countries can easily be juxtaposed for the purpose of a comparative analysis. The degree of similarities goes far beyond the above mentioned issues as the following detail will demonstrate: Whilst the only active resistance from within Europe towards Germany's reunification came from Margaret Thatcher's Conservative government in Britain, one of Korea's closest geographical neighbours also does not appear to be in favour of the unification of the Korean peninsula. For Japan, a unified Korean peninsula would not only form an influential political force (and rival) in East Asia but also a powerful economic competitor in the global market. "No doubt the combined economies of North and South, married to such a talented and well-educated people, would quickly rival Japan. That is one reason why Japanese leaders (...) have taken a dim view of Korean reunification, and in the past actively thwarted it by lining up almost exclusively with Seoul." [30] In both cases old and antiquated rivalries seem to outweigh contemporary political realism.

With particular reference to the politics of sport in divided Korea and Germany (Footnote VIII) there are two broad areas that warrant detail attention as both are frequently underpinned, framed and shaped by the reunification theme: First, the bidding for and hosting of mega sport events and mass spectacles, and, second, the use of international competitions to celebrate (and occasionally live) national unity.

There is little doubt that both South Korea and West Germany have been keen on hosting major sport events. Whilst the 1988 Summer Olympics in Seoul succeeded in displaying South Korea's technological and industrial advancement, and economic achievements to a world audience, the 2002 
Soccer World Cup was intended to be a "catalyst to create popular harmony, system stability and to promote a neo-liberal hegemony in Korea". [31] On both occasions the central government was largely successful. In contrast, the 1972 Summer Olympics in Munich failed to achieve its political objectives, namely the representation of the new, democratic and liberal Germany, as they were overshadowed by the terrorist attack on the Olympic village and the subsequent dismal failure of the German authorities and lawenforcement agencies to free the Israeli hostages. In addition, "since the GDR had been granted full rights by the I.O.C., the decision forced recognition of the East German flag, emblem, and anthem on West German soil." [32] Two years later, however, the Soccer World Cup managed to partly rehabilitate the German hosts due to their efficient and smooth organisation, the high quality football and the victory of the German team (Footnote IX). The latter contributed significantly to the consolidation of a distinctive national identity and to an improvement of Germany's global reputation. [33] Most recently Germany has successfully hosted the 2006 World Cup and impressed both travelling football fans as well as a global television audience with a colourful and entertaining sporting festival which will certainly be remembered for its unprecedented friendly, peaceful, positive and joyful atmosphere. For the Germans themselves this event marked a dramatic change in their attitude towards traditional symbols of nationalism, such as the national flag and anthem. For the first time since 1945 they were able to publicly and unreservedly embrace them without any threatening undertones.

However, West Germany's desire and justification to host major international sport events hardly ever included references to the relationship with the German Democratic Republic. Only Berlin's unsuccessful bid to host the 2000 Summer Olympics contained a low-key political rationale. The bidding committee argued that staging the Games in Berlin would have tremendous 
political symbolism signifying the end of the Cold War and the city's potential to bridge the gap between East and West. Furthermore, the Olympics would provide the city and the country with a global stage to celebrate a unified and rebuilt Germany that is prepared to play a leading role in the post Cold War Europe of the new millennium.

During the period of separation both German countries were more concerned with exploiting sport's potential to establish distinctive national identities and to exploit the playing fields as an arena for symbolic ideological battles, even if it stressed differences and indirectly consolidated the existing political division. According to Markus Wolf, the former head of the East German secret service, international sport events were also used for conspiratory meetings with their spies, e.g. "The Winter Olympics in Innsbruck, Austria, in 1976 provided good cover for a meeting." [34] In contrast, South Korea's political agenda attached to such events is largely dominated by reunification issues. This is most obvious in the documentation supplied to the International Olympic Committee in support of Pyeongchang's application to host the 2014 Winter Olympics.

The uniqueness of the Arirang festival provides the North Korean rulers with a rare and unrivalled opportunity to present the country to the rest of the world. Its perfect choreography, the active involvement of tens of thousands of citizens and its non-competitive spirit offers an alternative to the concept, norms and values of modern sport and celebrates an interpretation of physical culture which falls outside the dominant 'higher, faster, stronger' philosophy. This spectacle provides foreigners with the rare opportunity to visit this isolated country and the North Korean government with an inexpensive symbolic gesture demonstrating more openness and transparency. As the Arirang festival is currently one of the very few windows of opportunity for foreign journalists and camera teams to enter the 
DPRK, the archived visual footage from this spectacle is frequently used as a background to TV reports of natural disasters, catastrophic accidents or important political events. In contrast, East Germany relied almost completely on its track suit ambassadors' activities abroad.

The Arirang festival is also a contemporary reminder of the powerful Soviet influences on the development of sport and physical culture in both East Germany as well as North Korea. The spectacle draws heavily on two equally rehearsed and scripted events which emerged under Stalin: the theatrically orchestrated Physical Culture Days, with their choreographed and elaborate parades through Moscow's Red Square as well as "mass gymnastic displays, bizarre and idiosyncratic floats, and omnipresent portraits of Stalin", [35] and the Spartakiades which were "to be distinguished from the Olympics by the inclusion of military events, folk dances and noncompetitive pageants", although "the core of the progam ... was the same as that of the Olympics". [36] After the Russian Revolution the Bolshevik leaders decided not to take part in the modern Olympics since they rejected the aristocratic background of the movement's leaders and the amateurism dogma which, they argued, inhibited working class participation. Consequently, the emergence of the Spartakiad was an ideologically grounded attempt to offer an alternative to the 'bourgeois' multi-sport events of the Olympic movement.

With reference to the use of sport as a foreign policy tool there are hardly any commonalities. Both the divided Germany and Korea share(d) a belief in the positive virtues of an explicit and special foreign policy towards their neigbours that is based on encouraging change through rapprochement and engagement rather than isolation. However, in Germany sport was not included in this approach. Seven years after the end of World War II Germany was readmitted to the Olympic community. From 1956 to 1964 East and West Germany competed in the Olympic Games as one team using 
a non-partisan flag and Beethoven's 'Ode of Joy' as their anthem. Subsequently, the IOC agreed to the separate representation of the two German states which lasted for the next 24 years. During this period of time West and East Germany remained tough rivals right up to reunification in 1990. Even in the early 1970 s when a number of small steps were taken to normalise the relationship between the two German states, sport exchanges were not part of this agenda. Sporting encounters between the two German countries remained fiercely competitive until the collapse of the GDR. Ironically, the last time the two Germanys competed as separate countries at an Olympics was in Seoul in 1988. East Germany's outstanding sporting successes have been tainted by the subsequent knowledge that some of its athletes used performance-enhancing drugs. In sharp contrast, both Korean states have always competed separately at the Olympics. In Korea, however, cooperation in the world of sport is multi-dimensional and appears to be an important diplomatic tool although it lacks a systematic, structured and thought-through policy framework. Particularly since the beginning of the new millennium there have been a number of dramatic changes as a joint Korean team participated in the opening and closing ceremonies of various Summer and Winter Olympics. There appears to be a growing sense that due to the very difficult reunification situation both countries' governments see international sport as one of the few high profile and inexpensive ways of celebrating their common cultural heritage and keeping the political goal of unifying the divided peninsula in the public discourse.

Furthermore, there appears to be little rivalry on the playing fields between North and South Korea. Quite the opposite, the organisers of noncompetitive, friendly 'unification' matches continuously aim to stress harmony and unity, and celebrate historical and cultural commonalities. In fact, the dominant rivalry of both Koreas appears to be with Japan due to the country's colonial history and its attempt to completely annexe the 
Korean peninsula in the first half of the twentieth century. In sharp contrast, West and East German sporting encounters have always been tense and highly competitive. In a large number of popular German sport history books the 1-0 defeat to the East German team at the 1974 Soccer World Cup is described as one of the most embarrassing moments in West Germany's history. The regular superiority of the East German team at both the Summer and Winter Olympics has always been a thorn in the side of WestGerman politicians.

Due to its extremely limited resources and expertise it is very unlikely that in the near future the DPRK will be able to produce an Asian 'sports miracle' and impress the rest of the world with outstanding achievements and victories (as they did at the 1966 Soccer World Cup in England when they did not only cause the organizers some severe diplomatic headaches but also beat Italy to reach the quarter finals). [37] In contrast to the GDR, however, the North Korean government does not prevent the very small number of outstanding athletes the country has produced to seek employment abroad. In East Germany, the state's paranoia about athletes attempting to defect whilst on international duties went to such an extent, that a large number of 'minders', usually members of the secret service, always traveled with them to international competitions. In addition, a considerable amount of part-time spies (comprising fellow athletes, sport scientists, coaches, support staff, etc.) kept a detailed record of all athletes' behaviour, political opinions and, most importantly, commitment to the socialist state. [38] The story of the basketball player Ri Myong Hun clearly shows the different attitude of the DPRK's government as well as the obstacles North Korean top-level athletes face abroad.

At 2.40 meters ( $7 \mathrm{ft} 9 \mathrm{in}$ ), Ri Myong Hun is a giant among basketball players. He hoped to show NBA fans his passion for basketball as well as his 
skills, particularly the unique ability to dunk the ball with both feet on the ground. Naturally, it was his height that first caught the attention of several NBA teams but also his perfect shooting from the 3-point line. He was allowed to move to Canada in 1998 where his coach, Jack Donahue, put him on a strict regimen of weights, full court basketball, conditioning and even daily English lessons to get him ready for the NBA. After a short period of time several teams were interested in signing him. However, this never happened, as the US State and Treasury Departments' Foreign Assets Control regulations, also known as the 'Trading with the Enemy Act', bans American companies from doing business with North Korea and its citizens. The North Korean government had demanded that a proportion of Ri's salary should be given to the North Korean state. Ri returned home in 2000 where he continued to play for the national team and is considered a national hero. For North Korea this was obviously a missed (public relations) opportunity to initiate the development of an alternative discourse as outstanding foreign individual athletes have the power to shift the public's view. Their highprofile performances can replace dominant images, beliefs and perceptions that - in the case of North Korea as well as for example Cuba - tend to vilify other country's leaders and to demonize and stereotype other nations.

In a nutshell, after successfully hosting the Seoul Olympics in 1988 and the Soccer World Cup 2002 the South Korean government's foreign policy focus has now shifted. It tries to utilize sport not only for international recognition, national pride and prestige purposes but also as a tool to promote, grow and intensify dialogue with the North. Instead of focussing on differences and rivalries the emphasis is on celebrating commonalities and cooperation.

East Germany's political collapse and the subsequent reunification came as a total surprise to everybody, politicians, the people, and the global community. Although it had been on people's minds and part of the general 
political agenda and discourse, nobody expected it to happen so suddenly. Therefore the West German state was totally unprepared and the whole population still suffers from the catastrophic consequences of the rushed political and economic reunification. The dramatic exodus of many top-level East German athletes, in fact, contributed significantly to the collapse of the Socialist regime after the wall came down. The discontinuation of national sporting competitions was the most visible sign to everybody that East Germany's civil society was crumbling. In Korea, sport, in general, and interKorean sport exchanges, in particular, form an essential part of a reunification policy of small steps. There is a sense that Korean politicians not only want to learn from, and eventually avoid, the mistakes made in Germany but also that they have chosen sport to make a more positive and constructive contribution to the unification of the Korean peninsula which goes far beyond what Levermore and Budd have called the promotion of "détente between the two Koreas". [39] 


\section{Footnotes}

(I) Whenever the term 'Korea' is used, it refers to the Korean nation and peninsula as a whole deliberately ignoring the political division as this is a fairly recent phenomenon (commencing in 1948) considering the very long recorded history of this nation dating back approximately 5 millenniums.

(II) The Korea Foundation is an independent cultural and educational organization, affiliated to the Ministry of Foreign Affairs, and supported by public funding and private donations. The Foundation was established in 1991 with the aim of enhancing Korea's image and reputation in the world through the promotion of various academic and cultural exchange programmes. Amongst many other activities, it provides a wide range of fellowship grants for students and scholars with an interest in Korea to visit the country, to undertake research and to disseminate the results. For more details see: www.kf.or.kr

(III) The US has quietly maintained a long-term troop presence in South Korea, currently numbered at about 30.000, since intervening in the 1950-53 Korean War.

(IV) During the 1997 Asian financial crisis the International Monetary Fund (IMF) pledged South Korea US\$60 billion to help it weather the storm but attached harsh terms to this agreement forcing the government to introduce a programme of political reforms.

(V) In order to avoid any diplomatic embarrassment national flags were strictly prohibited.

(VI) Kim Dae Jung's innovative inter-Korean policy approach is often referred to as 'Nordpolitik'. Due to the large number of commonalities between the divided Germany and Korea, political scientists tend to use very similar terms which originated in the German context and language to describe and analyse the situation on the Korean peninsula. The term Ostpolitik, for example, refers to the specific set of political initiatives, policies and activities the West-German government developed and employed to deal with its neighbour in the East (German: Ost). As Korea is not divided in an Eastern and Western part but in North and South, the term Nordpolitik is the result of a linguistic adaptation process recognising the different geographical locations (Nord meaning North).

(VII) This in itself, i.e. being able to fly directly from Seoul to Pyongyang was a novelty and of extreme political significance as there are no direct flights between the two capitals. 
(VIII) Due to the limited scope of this paper other interesting comparisons have to be ignored, e.g. a juxtaposition of the Olympic achievements of all four countries which raises a number of questions about the different approaches to the production of top-level achievements in the world of sport.

(IX) As both the 1936 Nazi Olympics and the 1972 Munich Games had left German politicians with disastrous legacies, the organizers of the 1974 World Cup were deeply concerned about the safety of players and spectators and provided an army of security personnel from the armed forces and the police to protect the teams and fans, so that some observers labeled the event 'the World Cup of the Uniforms'.

\section{Endnotes}

[1] Sugden and Bairner, Sport in Divided Societies, 2

[2] Lenskij, Inside the Olympic Industry - Power, Politics and Activism

[3] Butler, 'Getting the Games: Japan, Korea and the co-hosted World Cup', 43-55

[4] Childs, 'The German Democratic Republic', 67-101. Damklaer, 'The Unification of German Sports Systems', 261-268. Hartmann, Goldkinder - Die DDR im Spiegel ihres Spitzensports. Hinsching, Alltagssport in der DDR. Merkel, 'The German Government and the Politics of Sport and Leisure in the 1990's: An Interim Report', 95-108. Merkel, 'Sport in Divided Nations - The case of the old, new and 're-united' Germany', 139-166. Naul and Hardman, Sport and Physical Education in Germany. Spitzer and Braun, Der geteilte deutsche Sport.

[5] Lee 'The development of football in Korea', 73-88

[6] Cumings, Korea's Place in the Sun - A Modern History, 248

[7] Amsden, Asia's Next Giant: South Korea and Late Industrialisation. Hwang, The Korean Economies. Ogle, South Korea: Dissent within the Economic Miracle. Woo, Race to the Swift: State and Finance in the Industrialization of Korea.

[8] Cumings, Korea's Place in the Sun - A Modern History, 299-341

[9] Cumings, Korea's Place in the Sun - A Modern History, 404-447

[10] Blair, The Forgotten War: America in Korea, 1950 - 1953. Cumings, Korea's Place in the Sun - A Modern History, 139-298. Zhang, Mao's Military Romanticism: China and the Korean War.

[11] Choo, 'Inter-Korean Cooperative Efforts to Normalize North Korea's Industry', 88-107

[12] Chamberlin, 'Peaceful Korean Unification: Is it feasible; is there a U.S. role?', 50-57

[13] Lee, 'After 15 Years of German Unification: Lessons for Korea', 1-3

[14] Harrison, 'South Korea, North Korea and the U.S. Alliance: Roh Moo-hyun's First Two Years', 12-17

[15] Hak, 'North Korea's Unification Policy', 27 
[16] Hak, 'North Korea's Unification Policy', 5

[17] Ha and Mangan, 'Ideology, Politics and Power: Korean Sport-Transformation, 1945 1992'

[18] Ha and Mangan, 'Ideology, Politics and Power: Korean Sport-Transformation, 1945 1992', 217

[19] Ministry of Unification, Peace and Prosperity - White Paper on Korean Unification 2005, 44-6 and 88-9

[20] Carr, 'The Involvement of Politics in the Sporting Relationships of East and West Germany', 1945-1972', 49

[21] The Korea Herald (14 April 2006). Hwang skates on thin ice between 2 Koreas (by Frances Yoon)

[22] KCNA (25 November 2005). Pyongyang-Nampho marathon for reunification

[23] Korea Times (5 April 2006). Inter-Korean sports programs boost PyeongChang's Olympic bid (by Lee Hyo-Sik)

[24] Korea Herald (15 August 2008) N. Korean kicked out while U.S. chases China

[25] The Guardian (17 May 2002). Despair, hunger and defiance at the heart of the greatest show on earth - Surreal North Korean party opens isolated state to the world (by Jonathan Watts)

[26] Washington Post Foreign Service (27 October 2005). North Korea Sends a 'Message to the World' - Secretive State Welcomes Visitors for Month-Long Celebration of Patriotism,

Talent (by Joohee Cho and Anthony Faiol) A12

[27] Joong Ang Ilbo (14 October 2005) North kicks segment off its Arirang show

[28] Washington Post Foreign Service (27 October 2005). North Korea Sends a 'Message to the World' - Secretive State Welcomes Visitors for Month-Long Celebration of Patriotism, Talent (by Joohee Cho and Anthony Faiol) A12

[29] Cumings, Korea's Place in the Sun - A Modern History, 508-9

[30] Cumings, Korea's Place in the Sun - A Modern History, 509

[31] Manzenreiter and Horne, 'Global governance in world sport and the 2002 World Cup Korea/Japan', 1-26

[32] Carr, 'The Involvement of Politics in the Sporting Relationships of East and West Germany', 1945-1972', 40-51

[33] Merkel, 'Soccer Made in Germany: Solid, Reliable and Undramatic but Successful', 93118

[34] Wolf, Man without a face - The memoirs of a spymaster, 134

[35] Edelmann, Serious Fun - A History of Spectator Sports in the U.S.S.R., 43

[36] Edelmann, Serious Fun - A History of Spectator Sports in the U.S.S.R., 38

[37] For a full account see Polley, 'The Diplomatic Background to the 1966 Football World Cup', $1-18$

[38] Spitzer, 'Im Schattenbereich - Inoffizielle Mitarbeiter im Sport: Fallstudie Leipzig', 188204

[39] Levermore and Budd, Sport and International Relations - An emerging relationship, 3 


\section{Reference List}

Advisory Council on Democratic and Peaceful Unification History of the Development of InterKorean Relations - Collection of Photographs. Seoul: Advisory Council on Democratic and Peaceful Unification, 2004.

Amsden, A. Asia's Next Giant: South Korea and Late Industrialisation. New York: Oxford University Press, 1989.

Blair, C. The Forgotten War: America in Korea, 1950 - 1953. New York: Times Books, 1987

Butler, O. 'Getting the Games: Japan, Korea and the co-hosted World Cup'. Japan, Korea and the 2002 World Cup edited by J. Horne and W. Manzenreiter. London: Routledge, 2002.

Carr, G. A. 'The Involvement of Politics in the Sporting Relationships of East and West Germany, 1945-1972'. Journal of Sport History, 7, No 1 (1980): 40-51

Chamberlin, P. F. 'Peaceful Korean Unification: Is it feasible; is there a U.S. role?'. Two Years of Roh Moo-hyun Administration - Achievements and Challenges edited by Korean Overseas Information Service Seoul. Government Publications, 2005.

Childs, D. 'The German Democratic Republic'. Sport under Communism edited by J. Riordan. London: Hurst \& Co, 1978.

Choo, W. S. 'Inter-Korean Cooperative Efforts to Normalize North Korea's Industry'. Korea Focus, 13, No. 6 (2005): 88-107

Cumings, B. Korea's Place in the Sun - A Modern History. New York: W.W. Norton \& Company, 2005.

Damklaer, S. 'The Unification of German Sports Systems'. Wilcox, R.C. ed., Sport in the Global Village. Morgantown: Fitness Information Technology, 1994.

Edelmann, R. Serious Fun - A History of Spectator Sports in the U.S.S.R.. Oxford: Oxford University Press, 1993.

Ha, N. G. and Mangan, J. A. 'Ideology, Politics and Power: Korean Sport-Transformation, 1945 1992'. The International Journal of the History of Sport. Vol. 19, No. 2-3 (2002): 213 242

Hak, S. P. 'North Korea's Unification Policy'. Korean Unification Strategies for the $21^{\text {st }}$ Century, Proceedings of the International Conference Commemorating the $50^{\text {th }}$ Anniversary of Kyungnam University, 22 - 23 May 1996 at the Seoul Hilton Hotel, 1996. 
Harrison, S. S. 'South Korea, North Korea and the U.S. Alliance: Roh Moo-hyun's First Two Years'. Two Years of Roh Moo-hyun Administration - Achievements and Challenge edited by Korean Overseas Information Service. Seoul: Government Publications, 2005.

Hartmann, G. ed. Goldkinder - Die DDR im Spiegel ihres Spitzensports. Leipzig: Forum Verlag Leipzig, 1998.

Hill, C. R. Olympic Politics. Manchester: Manchester University Press, 1996.

Hinsching, J. ed. Alltagssport in der DDR. Aachen: Meyer and Meyer Verlag, 1998.

Hobermann, J. M. Sport and Political Ideology. Austin: University of Texas Press, 1984.

Horne, J. and M. Manzenreiter, W. eds. Japan, Korea and the 2002 World Cup. London: Routledge, 2002.

Hwang, E. G. The Korean Economies. Oxford: Clarendon Press, 1993.

Kanin, D. B. 'Ideology and Diplomacy: The Dimension of Chinese Political Sport'. Sport and International Relations edited by B. Lowe, B., D. B. Kanin and A. Strenk. Champaign, Illinois: Stipes Publishing Company, 1978.

Lee, H. Y. 'After 15 Years of German Unification: Lessons for Korea'. Korea Focus, 13, No. 6 (2005): 1-3

Lee, J. Y. 'The development of football in Korea'. Japan, Korea and the 2002 World Cup edited by J. Horne and W. Manzenreiter. London: Routledge, 2002

Lenskij, H. Inside the Olympic Industry - Power, Politics and Activism. Albany: State University of New York Press, 2000.

Levermore, R. and A. Budd eds. Sport and International Relations - An emerging relationship. London: Routledge, 2004.

Manzenreiter, W. and J. Horne 'Global governance in world sport and the 2002 World Cup Korea/Japan'. Japan, Korea and the 2002 World Cup edited by J. Horne and W. Manzenreiter. London: Routledge, 2002.

Manzenreiter, W. and J. Horne, J. eds. Football goes East. Business, Culture and the People's Game in China, Japan and Korea. London: Routledge, 2004.

McBeth, J. 'Sporting Seoul awaits the five-ring circus'. Far Eastern Economic Review, April. (1988): $42-44$

Merkel, U. 'Soccer Made in Germany: Solid, Reliable and Undramatic but Successful'. Hosts and Champions - Soccer Cultures, National Identities and the World Cup in the USA edited by J. Sugden and A. Tomlinson. Avebury: Gower Press, 1994. 
Merkel, U. 'The German Government and the Politics of Sport and Leisure in the 1990's: An Interim Report'. Policy and Politics in Sport, Physical Education and Leisure edited by A. Tomlinson, M. Talbot and S. Fleming. Eastbourne: Leisure Studies Association Publication, 1995.

Merkel, U. 'Sport in Divided Nations - The case of the old, new and 're-united' Germany'. Sport in Divided Societies edited by J. Sugden, and A. Bairner. Aachen: Meyer and Meyer, 1999.

Ministry of Unification Peace and Prosperity - White Paper on Korean Unification 2005. Seoul: Ministry of Unification, Republic of Korea, 2005.

Naul, R. and K. Hardman, K. eds. Sport and Physical Education in Germany. London: Routledge, 2002.

Ogle, G. South Korea: Dissent within the Economic Miracle. Atlantic Highlands, N.J.: Zed Books, 1990.

Peppard, V. and J. Riordan Playing Politics: Soviet Sports Diplomacy to 1992. Greenwich, Conn.: Westport Press, 1993.

Polley, M. 'The Diplomatic Backgroundto the 1966 Football World Cup'. The Sports Historian. No 18, 2 (Nov. 1998): 1-18

Riordan, J. and P. Arnaud Sport and International Politics: The Impact of Fascism and Communism on Sport. London: E \& FN Spon, 1999.

Riordan, J. and A. Krüger eds. The International Politics of Sport in the $20^{\text {th }}$ Century. London: E \& FN Spon, 1999.

Spitzer, G., 'Im Schattenbereich - Inoffizielle Mitarbeiter im Sport: Fallstudie Leipzig'. Goldkinder - Die DDR im Spiegel ihres Spitzensports edited by G. Hartmann. Leipzig: Forum Verlag Leipzig, 1998.

Spitzer, G. and H. Braun eds., Der geteilte deutsche Sport. Köln: Sport und Buch Strauss, 1997.

Sugden J. and A. Bairner eds., Sport in Divided Societies. Aachen: Meyer and Meyer, 1999

Wolf, M., Man without a face - The memoirs of a spymaster. London: Jonathan Cape, 1997

Woo, J., Race to the Swift: State and Finance in the Industrialization of Korea. New York: Columbia University Press, 1991

Zhang, S. G., Mao's Military Romanticism: China and the Korean War. Lawrence: University Press of Kansas, 1995 